\title{
CARBON STORAGE POTENTIAL OF NATURAL AND PLANTED MANGALS IN TRANG, THAILAND
}

\author{
CADIZ, P. L. ${ }^{1,2,3}$ - CALUMPONG, H. P. ${ }^{3}$ - SinUtoK, S. ${ }^{2,4}-$ CHOTIKARN, P. ${ }^{1,2,4 *}$ \\ ${ }^{1}$ Marine and Coastal Resources Institute, Prince of Songkla University, Hat Yai 90110, \\ Thailand
}

${ }^{2}$ Coastal Oceanography and Climate Change Research Center, Prince of Songkla University, Hat Yai 90110, Thailand
${ }^{3}$ Silliman University Institute of Environmental and Marine Sciences, Dumaguete City 6200, Philippines

${ }^{4}$ Faculty of Environmental Management, Prince of Songkla University, Hat Yai 90110, Thailand

*Corresponding author

e-mail: ponlachart.c@psu.ac.th; phone: +66-74-282-335; fax: +66-74-212-782

(Received 10 ${ }^{\text {th }}$ Dec 2019; accepted $6^{\text {th }}$ May 2020)

\begin{abstract}
This study aims to investigate the carbon storage potential for 25 year-old (planted) and $>50$ year-old (natural) mangrove stands and mangrove sediment, in three districts of Trang province, Thailand. The results show a lower carbon content in the aboveground biomass of 10-25-year-old (planted) stands than in the $>50$-year old (natural) stands. However, we found more organic carbon in sediments in planted sites than in natural sites, which could be partly due to the higher tree densities in the former. The derived organic carbon in particulate matter was lower in the planted forest than in the natural forest, which could be due to allochthonous inputs of organic matter from rivers and creeks, and to a higher number of species in the natural forests. This study demonstrated that the amount of carbon stored in mangroves increases with age, but the amount of carbon stored in mangrove soils could vary with mangrove density, sediment size, allochthonous inputs, and inundation. This study suggested that planted and natural mangrove forests can capture and store a substantial amount of carbon. Such information could motivate policymakers and local communities to conserve the last remaining mangrove forests, rehabilitate degraded ones, and replant abandoned fish and shrimp ponds.
\end{abstract}

Keywords: carbon content, organic matter, carbon sink, reforested mangroves, mangrove ecosystem

\section{Introduction}

Coastal ecosystems such as mangrove forests, saltmarshes, and seagrass meadows have a significant role in mitigating climate change impacts through carbon sequestration. McLeod et al. (2011), reported that fifty-five percent of the carbon can be sequestered in the vegetated coastal ecosystem (mangrove forest, seagrass beds, and salt marshes), because of their ability to store "blue C" in deep organic soils. "The blue C" refers to all the carbon captured from the ocean, including mangrove forests, seagrasses, meadows, and tidal saltmarshes (Thomas, 2014).

Mangroves are known as a diverse group of plants that grow in tropical to subtropical marine intertidal and estuarine areas (Tomlinson, 1986). The unique characteristics of the root systems of mangroves slow down the incoming tidal waters and allow organic and inorganic materials to settle on top of the sediment (Hutchings and Saenger, 1987) and thereby they mitigate siltation (Thampanya et al., 2006). These roots can also act as nursery grounds (Beaumont et al., 2014). The big trees act as buffer against waves (Horstman et al., 2012), and most importantly mangrove litter 
is a source of nutrients (Boullion et al., 2008). However, these functions are often overlooked and mangroves are valued by humans for the goods they provide, such as charcoal and firewood, tannin, medicines, and as source of fishery products such as shellfish, crabs and shrimps (Aksornkoae, 1993). Mangroves are also often considered an "open access" resource for the local people. As such, mangroves remain among the most threatened ecosystems in the world, cut and cleared at an alarming rate (Valiela et al., 2001). The global estimates were as high as 15,642,673 (FAO, 2007) to $17,000,000$ ha of mangroves in 5 countries of the world (Saenger et al., 1983) and trimmed down to $10,354,335$ ha in 15 countries (Giri et al., 2011) during the 80's to 90's. The losses were rated at 1-2 percent per year by UNEP (2004), and particularly high in Asia due to massive aquaculture activities, urban settlements, and industrialization (Lewis, 2005; Primavera and Esteban, 2008; Romanach et al., 2018).

In Thailand, the mangrove area was recorded as 367,900 ha in 1961 (Aksornkoae, 1993; Havanond, 1997) and were reduced to 245,533 ha by 2015 (DMCR, 2015). Mangrove deterioration occurred especially during the 80's when intensive shrimp farming and commercialization converted 5,700 ha of mangrove (Boromthanarat et al., 1991; Bantoon, 1994; Yee, 2010), causing major attention because some converted shrimp pond areas were left abandoned or unattended after the economic crises of the shrimp farming industry. The Government of Thailand conducted massive rehabilitation and conservation programs (Fast and Menasvita, 2003) backed-up with legislation and enforcement of laws and regulations on mangrove uses (Aksornkoae, 2012). The significant value of restoring mangrove areas was fully recognized after the Indian Ocean tsunami hit the Andaman areas of Thailand in 2004 (Barbier, 2008). Massive rehabilitation and reforestation spread out in various provinces, particularly in areas with land use change from shrimp farming activities. However, there was lack of monitoring whether these rehabilitation programs are ecologically sound and beneficial to restore degraded mangrove ecosystems, in particular with land use in shrimp farming. In Trang, land-use changes consisted by 2 percent of aquaculture land, by 47 percent of pararubber plantations, and by 17 percent of mangrove forest/evergreen forests and others classified as institutional land development, cities, paddy field, water bodies etc. (Land Use Development, 2013). Thus, this study is significant to Thailand's marine resources, particularly mangroves that are still threatened by land-use changes.

Overall, increasing awareness of the carbon storage potential of mangrove ecosystems remains a prerequisite for alleviating climate change issues. This study addresses the community structure and carbon capture potential of mangrove with land-use changes from shrimp farming activities and natural stands of mangroves in Trang, Southern Thailand. Two aged group of mangrove forests, the 10-25-years old (YO) planted in mangrove areas with land-use change from shrimp farming activities and $>50-$ YO natural stands, were measured and monitored in the study. The research findings provide information on the community structure of mangroves in Trang, Southern Thailand, and the carbon data obtained will serve as baseline information for future climate change impact studies. Overall this study helps recommend management strategies in promoting the functional role of mangrove as a source and sink of carbon for better management, protection, and conservation of mangrove forests in Southern Thailand. 


\section{Materials and Methods}

\section{Description of the Study Site}

The study sites were located in Sikao $\left(7.478961^{\circ} \mathrm{N}, 99.335952^{\circ}\right.$ E), Kantang $\left(7.376096^{\circ} \mathrm{N}, 99.57253^{\circ} \mathrm{E}\right)$ and Palian $\left(7.125833^{\circ} \mathrm{N}, 99.622948^{\circ} \mathrm{E}\right)$ districts of Trang, Southern Thailand (Fig. 1) where both 10-25-year old planted mangrove forest and $>50$-YO natural mangrove forest are found. In Trang, mangroves cover 249,331.25 ha of which 35,665.00 ha are designated as economic zone and 26,425.00 ha as preservation zone (Aksornkoae, 1993). Most of the mangroves in these districts are still pristine, except for some areas that have been excavated for shrimp farming 3-4 decades ago. These characteristics are common in these three districts: the areas have abandoned shrimp ponds, with some that have been reverted back into mangrove areas. The plantings of mangrove were mostly initiated by the Department of Marine and Coastal Resources (DMCR) and Thai Royal Department of Forestry (Havanond, 1997).

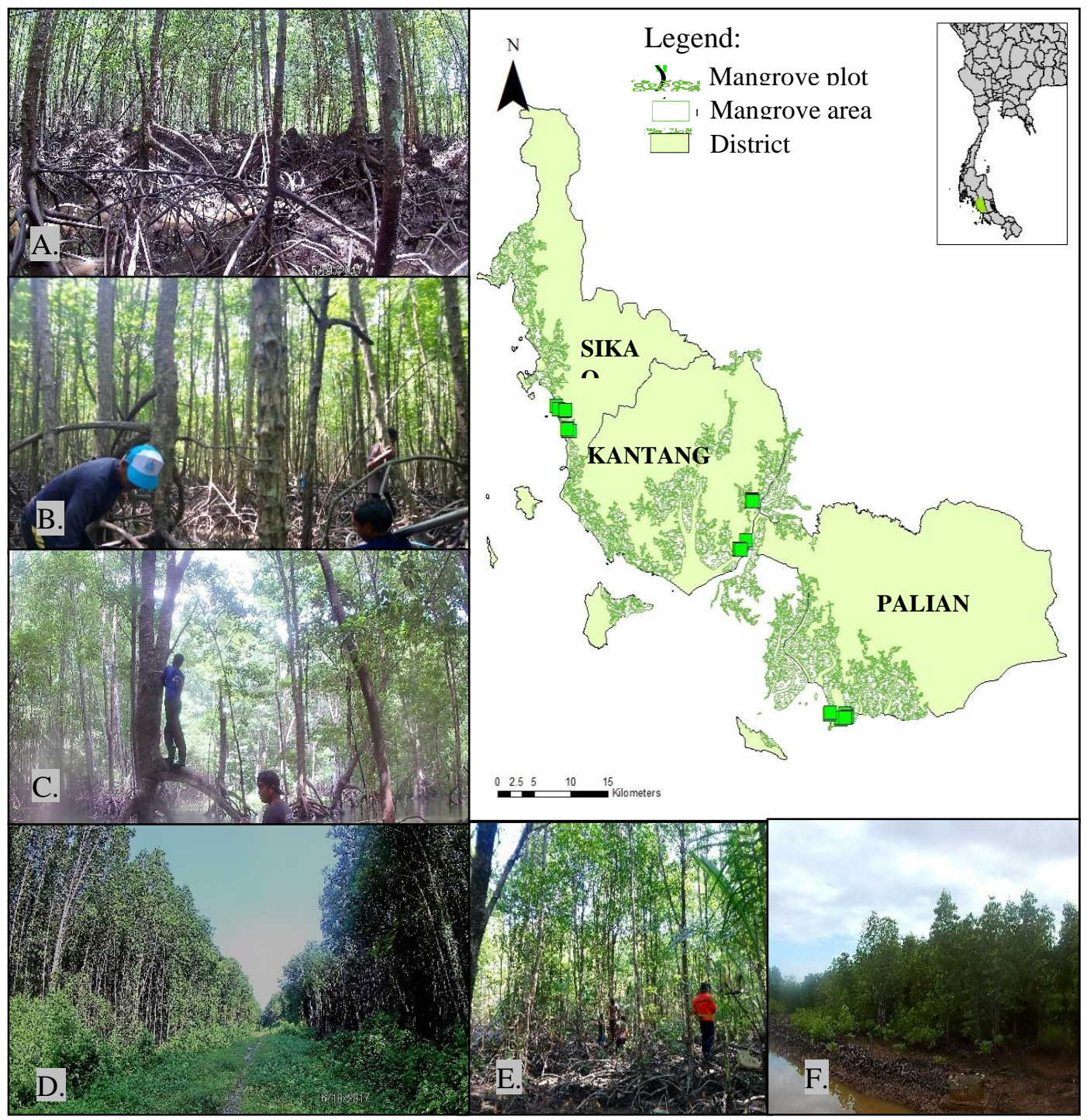

Figure 1. Map of the study sites showing the 3 districts, mangrove areas and permanent plots (green box) in Trang. A, D, and E are planted mangrove forest. $B, C$, and $F$ are natural mangrove forest. Inset: Map of Thailand 
There were ten permanent sampling plots (measuring 10x10 m) established in each district (Fig. 1). The sampling plots for the natural forest established in Sikao (SD) were located near a creek, bordered by Pakmeng Beach on the seaward side, while plots for the planted forest were located further southward. In Palian (PD), the plots were established along Palian estuary. The PD estuary is a junction between two big rivers of Klong Lak Khan and Khlong Rae (Horstman et al., 2013). In Kantang (KD), the plots were established inland, with an abandoned shrimp pond adjacent to the rubber plantation that has been replanted (Fig. 1D), while plots for the natural forest were located along the creeks and tributaries of KD River. The creeks and rivers receive water from adjacent shrimp pond areas and neighboring households. All plots are affected by the ebb and flow of the tides, except in SD where some of the plots established are inundated only during high tide due to large boulder crab mounds. The plots in PD were established near a concession area where most of the planted mangroves are cut for wood and construction materials (Fig. $1 F)$.

\section{Carbon in Aboveground Standing Biomass (CAGB)}

To determine the age of a forest, secondary information was obtained from the Department of Marine and Coastal Resources (DMCR). The profile and vegetation structure, such as species composition, density, basal areas, and biomass were obtained (Cadiz and Chotikarn, 2018). Profiling of the community structure was only conducted once, in April 2017. The above-ground biomass estimates followed the allometric equations of Komiyana et al. (2008), using diameter at breast height (D), wood density $(\rho)$ and with coefficient of determination $\left(\mathrm{r}^{2}\right)$ of 0.979 (Eq.l).

$$
\text { Above ground biomass }(\mathrm{kg})=0.251 \rho \mathrm{D}^{2.46}
$$

The AGB in kg was then converted to tonnes per hectare. The carbon content of standing biomass was obtained from tree biomass multiplied by 50 per cent, as shown below (Kauffman and Donato, 2012):

C content of each tree $(\mathrm{kgC})=$ tree biomass $(\mathrm{kg}) \times$ conversion factor $(0.5)$

\section{Dry Bulk Density}

The protocols for soil organic carbon (OC) were modified from Kaufman and Donato (2012), Schumacher (2012) and Hoyle (2013), where three parameters were considered to quantify soil carbon pool: 1. Soil depth, 2. Soil bulk density, and 3. Organic carbon concentration. In the determination of soil bulk density, the soil samples were taken in a known volume of $98.17 \mathrm{~cm}^{3}$ with a metal corer, oven dried at $60^{\circ} \mathrm{C}$, and weighed. The bulk density was calculated as the ratio of the dry mass of soil sample to its volume:

$$
\text { Dry bulk density }\left(\mathrm{g} \mathrm{cm}^{-3}\right)=\frac{\text { Massof dry soil }(\mathrm{g})}{\text { Original volume sampled }\left(\mathrm{cm}^{-3}\right)}
$$


Soil mass at specified depth $(\mathrm{mg})=$ Bulk Density $\left(\mathrm{mg} \mathrm{m}^{-3}\right) \times 10,000\left(\mathrm{~m}^{2}\right) \times \operatorname{Depth}(\mathrm{m})($ Eq.4)

Soil $\mathrm{C}_{\text {at specifieddepth }}(\mathrm{mg})=\frac{\text { Soil mass }_{\text {at specifieddepth }}(\mathrm{mg}) \times \% \mathrm{OC}_{\text {at specifieddepth }}}{100}$

\section{Organic Carbon in Soil Sediments and Organic Matter: Field Sampling and Processing of Soil Samples}

The fieldwork was carried out quarterly, in May, August, and November of 2017, and in February of 2018, for one year. August and November represent the wet season and May and February represent the dry season. Thirty permanent plots, measuring $10 \times 10 \mathrm{~m}$, were established and quarterly monitored in both $10-25-\mathrm{YO}$ planted and $>50$-YO natural mangrove stands in the three districts.

Sediment cores were taken from a $100 \mathrm{~m}^{2}$ plot in each district $(\mathrm{n}=5)$ and extracted for organic carbon (OC-S). The sediments extracted for organic carbon were sampled from the depths of $0-15,15-30,30-50$ and $50-100 \mathrm{~cm}$. Sediment sampling was done using a locally manufactured stainless soil corer measuring $5 \mathrm{~cm}$ in diameter and 175 $\mathrm{cm}$ in length. The volume of the cored OC-S totaled $98.17 \mathrm{~cm}^{3}$. The soil samples collected quarterly were oven dried at $60^{\circ} \mathrm{C}$ to a constant weight that was recorded. In preparation for CHN Analysis using CN 628 (LECO Corporation), all the quarterly soil subsamples were cleared from any large particles and wood debris, homogenized, and brought to the Faculty of Science, Prince of Songkla University.

The organic carbon derived from particulate organic matter (OC-POM) in soil samples is classified as the organic component of the soil, which is humus formed by the decomposition of leaves and other plant materials. The OC-POM contents were determined from the Loss on Ignition (LOI). The coring of the sediments was performed three times in each plot $(\mathrm{n}=3$ per plot) and the soil cores were extracted for depths of 0-15 and $15-30 \mathrm{~cm}$, making a total of 15 subsamples $(n=15)$ for each district. The volume of the soil core was constant at $294 \mathrm{~cm}^{3}$. Along with the soil classification, volumetric measurements were applied for further soil classification (Braley, 1992) as the soil was passed through a series of sieves, and the organic matter retained by the 1-2 mm mesh size was collected and air dried (Calumpong and Cadiz, 2012). After drying, the collected $\mathrm{OM}$ was put in an oven (Memmert UNB 500) at $60^{\circ} \mathrm{C}$ until constant weight. From the original weight of the OM/humus, a portion of dried OM or subsample was weighed into a crucible. The crucibles were placed in a muffle furnace (Digital Muffle Furnace FX-14) at $450-500^{\circ} \mathrm{C}$ for 4 to 5 hours. The organic matter content was calculated and converted to $\mathrm{Mg} \mathrm{C} \mathrm{ha}^{-1}$ (Howard et al., 2014) as follows:

$$
\% \mathrm{OM}=\frac{\text { Massof oven dried soil or humus }(\mathrm{g})-\text { ashed soil or humus }(\mathrm{g})}{\text { Massof original volume sampled }(\mathrm{g})} \times 100(\text { Eq.6) }
$$




\section{Physicochemical Parameters}

Measurements of redox (Eh), $\mathrm{pH}$, and temperature were done in situ using a handheld portable ORP and $\mathrm{pH}$ meter (WTW 3210). The probe was inserted into the soil at 0-2 cm depth. Three readings were taken during the day between 9:00 am to 3:00 pm within the sampling period. Rainfall data were obtained from the Meteorological Department, Trang.

\section{Statistical Analyses}

Multivariate analysis was used to determine significant differences in CAGB and OC-S and other related parameters, by site and by month. Two-way ANOVA was also used to determine significant differences in OC-S by mangrove age and by sampling month. Levene's test was applied in ANOVA for the equality of variances. When no significant differences were noted, the data were pooled by age and season and analyzed with a T-test. Post-hoc testing was performed to determine the variations by age (10-25-YO planted and >50-YO natural) and by season (wet and dry). Normality was tested with Shapiro-Wilk's test. Regression analysis was performed to find out the relationship between the production of OM and OC-POM, and DBD and OC-POM.

\section{Results}

\section{Carbon Captured in Above Ground Biomass (CAGB)}

The highest CAGB among all the sites was recorded in $\mathrm{KD}$ at $236.42 \pm 35.17 \mathrm{t} \mathrm{C} \mathrm{ha}^{-1}$, followed by PD at $181.30 \pm 23.25 \mathrm{t} \mathrm{C} \mathrm{ha}^{-1}$. The lowest was found in SD at $163.15+27.36 \mathrm{t} \mathrm{C}^{-1}$. Results on CAGB combined by the two ages (10-25-YO planted and $>50-$ YO natural forests) in all sites showed that the 10-25-YO planted forest had lower CAGB $\left(143.37 \pm 19.12 \quad \mathrm{t} \quad \mathrm{C} \quad \mathrm{ha}^{-1}\right)$ than $>50$-YO natural forest $\left(243.88 \pm 22.22\right.$ t C ha $\left.^{-1}\right)(p<0.001 ;$ Table 1$)$.

Table 1. Mean values of the vegetation structure

\begin{tabular}{|c|c|c|c|c|c|c|c|}
\hline $\begin{array}{l}\text { Site/ } \\
\text { Age }\end{array}$ & $\begin{array}{c}\text { DE } \\
\left(\text { stem ha }^{-1}\right)\end{array}$ & $\begin{array}{c}\text { BA } \\
\left(\mathbf{m}^{2} \mathbf{h a}^{-1}\right) \\
\end{array}$ & $\begin{array}{c}\text { Height } \\
\text { (m) }\end{array}$ & $\begin{array}{c}\text { Biomass } \\
\left(\mathbf{t ~ h a}^{-1}\right)\end{array}$ & $\begin{array}{c}\text { CAGB } \\
(\mathrm{t} \mathrm{C} \mathrm{ha-1)})\end{array}$ & $\begin{array}{c}\text { OC-S } \\
\left(\mathrm{Mg} \mathrm{C} \mathrm{ha}^{-1}\right)^{*}\end{array}$ & $\begin{array}{l}\text { OM } \\
(\%) \\
\end{array}$ \\
\hline $\begin{array}{c}\text { SD } \\
10-25\end{array}$ & $\begin{array}{r}1650.00 \\
\pm 583.90 \\
\end{array}$ & $\begin{array}{r}0.72 \\
\pm 0.05 \\
\end{array}$ & $\begin{array}{r}15.32 \\
\pm 0.38 \\
\end{array}$ & $\begin{array}{r}283.39 \\
\pm 100.23 \\
\end{array}$ & $\begin{array}{r}141.70 \\
\pm 50.12 \\
\end{array}$ & $\begin{array}{r}193.62 \\
\pm 15.31 \\
\end{array}$ & $\begin{array}{l}18.04 \\
\pm 2.17 \\
\end{array}$ \\
\hline $\begin{array}{c}\mathrm{SD} \\
>50\end{array}$ & $\begin{array}{c}1360 \\
\pm 286.05 \\
\end{array}$ & $\begin{array}{r}1.19 \\
\pm 0.10 \\
\end{array}$ & $\begin{array}{l}15.41 \\
\pm 0.19 \\
\end{array}$ & $\begin{array}{l}369.22 \\
\pm 50.11 \\
\end{array}$ & $\begin{array}{l}184.61 \\
\pm 25.05\end{array}$ & $\begin{array}{l}214.35 \\
\pm 15.91 \\
\end{array}$ & $\begin{array}{l}23.44 \\
\pm 1.82 \\
\end{array}$ \\
\hline $\begin{array}{c}\mathrm{KD} \\
10-25 \\
\end{array}$ & $\begin{array}{l}6220.00 \\
\pm 459.78 \\
\end{array}$ & $\begin{array}{r}0.57 \\
\pm 0.02 \\
\end{array}$ & $\begin{array}{l}15.71 \\
\pm 0.20 \\
\end{array}$ & $\begin{array}{l}325.08 \\
\pm 46.25 \\
\end{array}$ & $\begin{array}{l}162.54 \\
\pm 23.13 \\
\end{array}$ & $\begin{array}{l}317.75 \\
\pm 16.18 \\
\end{array}$ & $\begin{array}{l}23.14 \\
\pm 1.83 \\
\end{array}$ \\
\hline $\begin{array}{l}\mathrm{KD} \\
>50 \\
\end{array}$ & $\begin{array}{c}616.00 \\
\pm 131.76 \\
\end{array}$ & $\begin{array}{r}2.47 \\
\pm 0.25 \\
\end{array}$ & $\begin{array}{l}16.27 \\
\pm 0.35 \\
\end{array}$ & $\begin{array}{r}620.60 \\
\pm 95.99 \\
\end{array}$ & $\begin{array}{l}310.30 \\
\pm 47.99 \\
\end{array}$ & $\begin{array}{l}257.98 \\
\pm 13.04 \\
\end{array}$ & $\begin{array}{l}19.52 \\
\pm 1.61 \\
\end{array}$ \\
\hline $\begin{array}{c}\text { PD } \\
10-25\end{array}$ & $\begin{array}{c}3667.78 \\
\pm 1364.81 \\
\end{array}$ & $\begin{array}{r}0.30 \\
\pm 0.02 \\
\end{array}$ & $\begin{array}{l}15.71 \\
\pm 0.20 \\
\end{array}$ & $\begin{array}{l}251.72 \\
\pm 50.05\end{array}$ & $\begin{array}{l}125.86 \\
\pm 25.02 \\
\end{array}$ & $\begin{array}{l}305.24 \\
\pm 29.75\end{array}$ & $\begin{array}{r}16.31 \\
\pm 14.52 \\
\end{array}$ \\
\hline $\begin{array}{l}\mathrm{PD} \\
>50\end{array}$ & $\begin{array}{c}560.71 \\
\pm 103.55 \\
\end{array}$ & $\begin{array}{r}1.19 \\
\pm 0.13 \\
\end{array}$ & $\begin{array}{l}15.87 \\
\pm 0.19 \\
\end{array}$ & $\begin{array}{l}473.48 \\
\pm 32.84 \\
\end{array}$ & $\begin{array}{l}236.74 \\
\pm 16.42 \\
\end{array}$ & $\begin{array}{l}293.58 \\
\pm 13.91 \\
\end{array}$ & $\begin{array}{r}44.39 \\
\pm 14.52 \\
\end{array}$ \\
\hline
\end{tabular}

DE-depth, BA-basal area and H-height (Source: Cadiz and Chotikarn, 2018) CAGB-carbon in aboveground biomass, OC-S-organic carbon in soil and OM-organic matter in 10-25-YO and >50-YO mangrove forests in Trang, Thailand. * 1 metric ton $=1$ mega gram $(\mathrm{Mg})$ or 1000000 grams. Data represents Mean \pm S.E. 
According to the species with the most biomass was indicated in Rhizophora apiculata $\mathrm{Bl}$. in both of the 10-25-YO planted and >50-YO natural forests in KD at $464.25 \pm 130.16 \mathrm{t} \mathrm{ha}^{-1}$ and 325.08 $\pm 46.25 \mathrm{t} \mathrm{ha}^{-1}$, respectively (Cadiz and Chotikarn, 2018). The higher biomass of these species also corresponds to the species of higher CAGB found in both 10-25 planted and $>50$-YO natural mangrove forests in the three sites as well ( $p<0.05$; Tables 1 and 2 ). The R. apiculata were consistently high in most of the sites, particularly in $>50$-YO natural forest in $\mathrm{KD}\left(213.55 \pm 59.88 \mathrm{t} \mathrm{C} \mathrm{ha}^{-1}\right)$. Among the species measured, the CAGB of $R$. apiculata were highest in all sites and between planted and natural sites (Fig. 2). For some species such as Avicennia marina (Forssk.) Vierh. and Ceriops tagal (Perr.) CB Rob, the CAGB located in PD >50-YO natural forest ranged from $1.50 \pm 1.50 \mathrm{t} \mathrm{C} \mathrm{ha}^{-1}$ to $45.10 \pm 22.41 \mathrm{t} \mathrm{C} \mathrm{ha}^{-1}$.

Table 2. ANOVA test to determine the significant effects of biomass in three different sites, age and sites vs. age at $p<0.05$

\begin{tabular}{c|c|c|c|c}
\hline Source & df & SS & F & $\boldsymbol{p}$ \\
\hline Site & 2 & 139614451.43 & 25.87 & $<0.001$ \\
Age & 1 & 522219678.84 & 193.53 & $<0.001$ \\
Site vs. Age & 2 & 180661336.55 & 33.47 & $<0.001$ \\
\hline
\end{tabular}

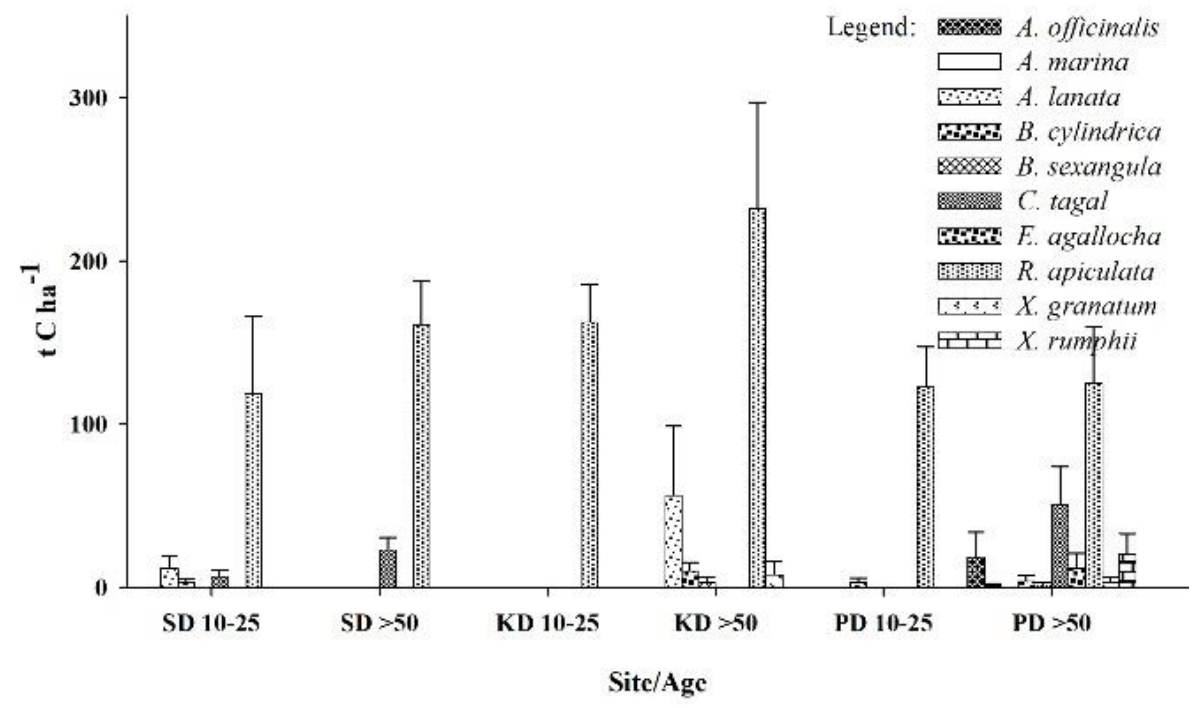

Figure 2. Carbon content ( $\left.t C h a^{-1}\right)$ of the different species calculated from AGB

\section{The Organic Carbon Stored Below Ground}

Among the various sites, the organic carbon stored in the soil (OC-S) was significantly highest in PD at $299.41 \pm 15.60 \mathrm{Mg} \mathrm{C}^{-1}$, followed by $\mathrm{KD}$ at $288.31 \pm 14.07 \mathrm{Mg} \mathrm{C}^{-1}$ The least was observed in SD at 203.12 $\pm 10.95 \mathrm{Mg} \mathrm{C}^{-1}$. Comparing between planted and natural mangrove, the 10-25-YO planted forest showed higher OC-S $\left(272.49 \pm 14.55 \mathrm{Mg} \mathrm{C}^{-1}\right)$ than the $>50-\mathrm{YO}$ natural mangrove forest $\left(254.73 \pm 10.93 \mathrm{Mg} \mathrm{C} \mathrm{ha}^{-1} ; p>0.05\right)$. A three-way ANOVA revealed no significant interaction among the sites, the months, and between planted and natural stands of mangroves ( $p>0.05$; Fig. 3). The 10-25-YO planted mangrove at KD and PD obtained 
the OC-S values of $317.75 \pm 16.18 \mathrm{Mg} \mathrm{C}^{-1}$ and $305.24 \pm 29.75 \mathrm{Mg} \mathrm{C}^{-1}$, respectively (Fig. 3). Statistically significant variations only showed up in the mean quarterly OC-S in PD >50-YO natural forest, which was highest in August (377.46 $\pm 14.21 \mathrm{Mg} \mathrm{C} \mathrm{ha}^{-1}$ ), followed by PD 10-25-YO planted forest in November (359.67 $\left.\pm 27.68 \mathrm{Mg} \mathrm{C} \mathrm{ha}^{-1}\right)$. The SD 10-25-YO planted forest had the lowest OC-S at $171.10 \pm 22.87 \mathrm{Mg} \mathrm{C} \mathrm{ha}^{-1}$ in February (Fig. 3).

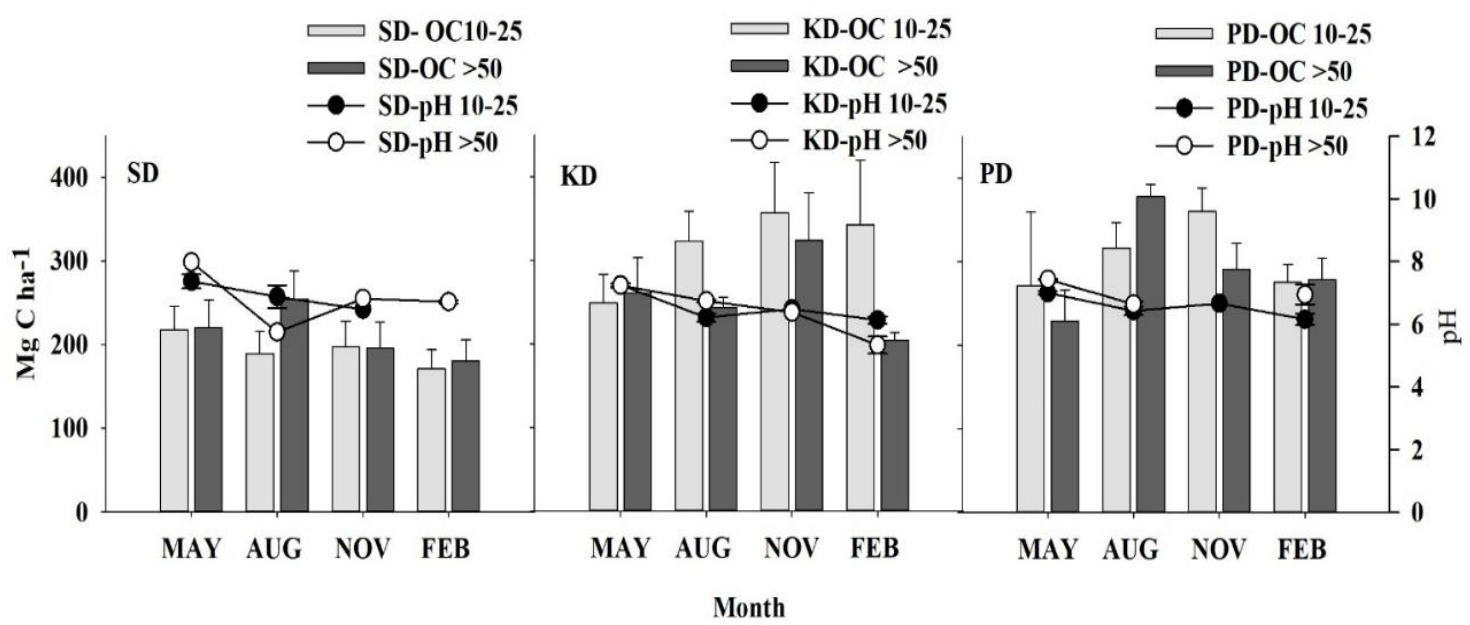

Figure 3. Organic Carbon stock from soil $(O C-S)\left(M g-C h a^{-1}\right)$ and $p H$ at different sites in 1025-YO planted and >50-YO natural mangrove forests. Error bars are for S.E.

Figures 4 and 5 show the overall mean OC-S for wet and dry seasons. The mean OC-S in wet season was significantly higher $\left(285.52 \pm 12.49 \mathrm{Mg} \mathrm{C} \mathrm{ha}^{-1}\right)$ than in the dry season $\left(241.99 \pm 12.71 \mathrm{Mg} \mathrm{C} \mathrm{ha}^{-1} ; p<0.05\right.$; Fig. 4).

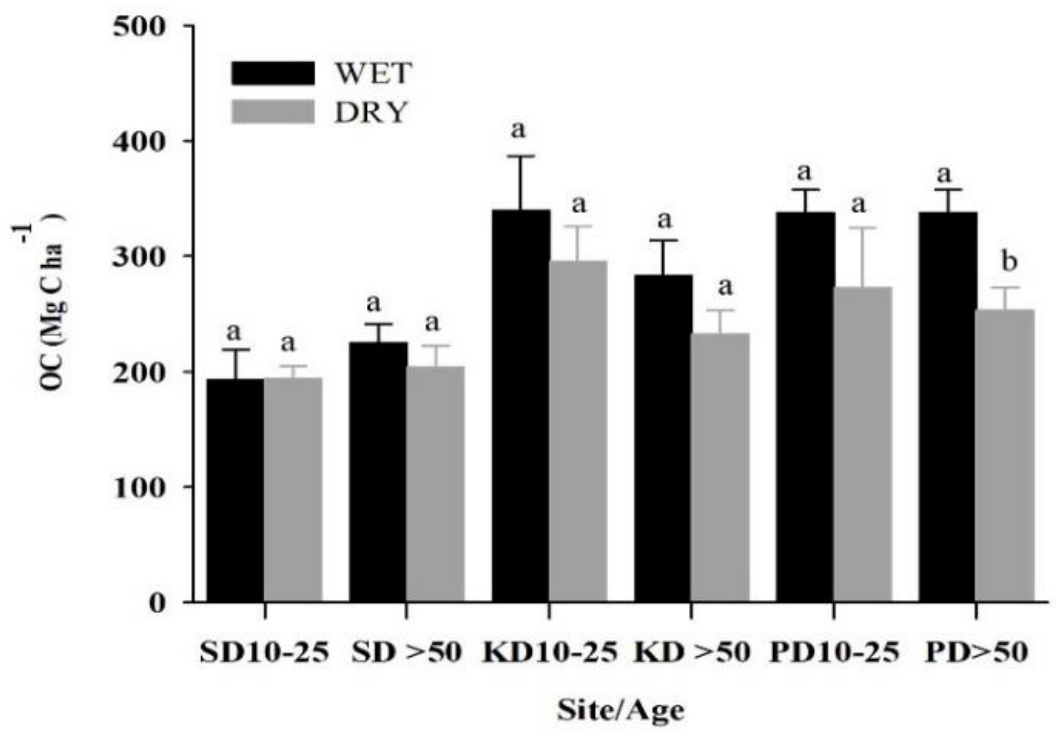

Figure 4. Overall mean $O C-S\left(M g C h a^{-1}\right)$ in the soil sediments between wet and dry seasons and 10-25-YO planted forest and >50-YO natural mangrove forests. Error bars are for S.E. ' $a$ ' on top of the error bar indicates $p<0.05$ while $b$ indicates $p>0.05$ in the different sites; $n=5$ 


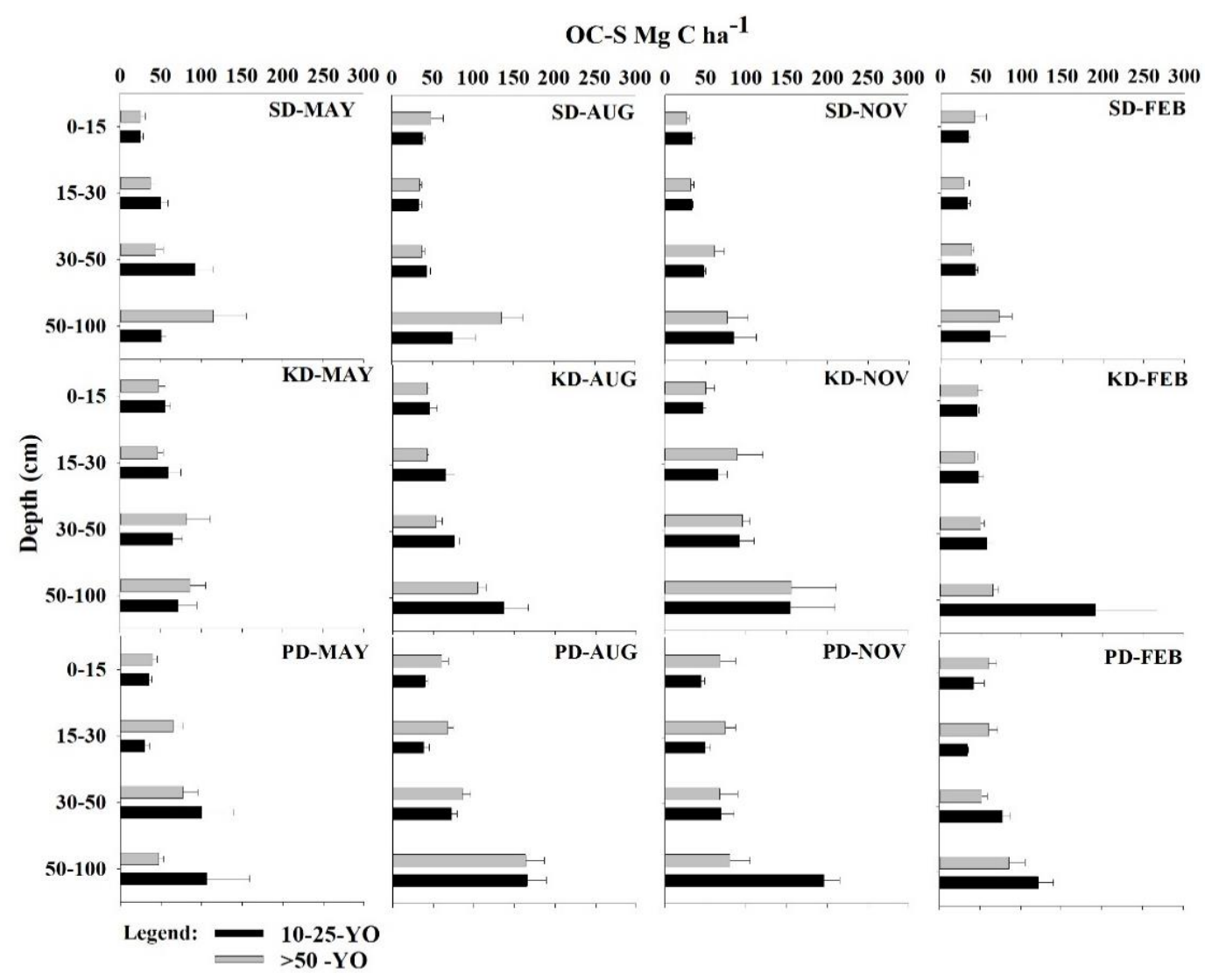

Figure 5. Organic carbon from soil $\left(\mathrm{Mg} \mathrm{Cha}^{-1}\right)$ stored in various depths in 10-25-YO planted and >50-YO natural mangrove forests in Trang, Thailand, sampled in August 2017 to February 2018. The error bars are for S.E.

Figure 5 shows a summary of the mean quarterly OC-S and Figure 6 shows the OC-S in each site and at various depths. The OC-S content varied with depth (0-15, 15-30, 30-50 and 50-100 cm depths). A factorial ANOVA indicated significant differences between 10-25-YO planted and $>50$-YO natural forests in PD ( $\mathrm{df}=3.32$ and 5.96; $p<0.05)$ and no significant differences were indicated in $\mathrm{SD}(\mathrm{df}=3.32$ and 2.30, $p>0.05)$ and $\mathrm{KD}(\mathrm{df}=3.32$ and $1.04 ; p>0.05)$ (Table 3). However, the overall trends across various depths in different sites showed higher OC-S at 50-100 $\mathrm{cm}$ depth in both 10-25-YO planted and >50-YO natural forest (Fig. 5). The values ranged from $27.19 \pm 2.25 \mathrm{Mg} \mathrm{C} \mathrm{ha}^{-1}$ found in 0-15 $\mathrm{cm}$ depth in SD 10-25-YO planted forest to $161.17 \pm 25.79 \mathrm{Mg} \mathrm{C} \mathrm{ha}^{-1}$ found in $50-100 \mathrm{~cm}$ depth in PD 10-25-YO planted forest (Fig. 5).

\section{Dry Bulk Density}

The trends in average Dry Bulk Density (DBD) of the sediments followed the same patterns as seen in OC-S. Overall DBD comparison between the two ages showed that 10-25-YO was higher $\left(2.57 \pm 0.72 \mathrm{~g} \mathrm{~cm}^{-3}\right)$ and $>50$-YO forest was lower $\left(2.34 \pm 0.17 \mathrm{~g} \mathrm{~cm}^{-3}\right)$ (Fig. 6B). In terms of the season, the results on DBD are similar to OC-S. It was higher during the wet season $\left(3.10 \pm 0.11 \mathrm{mg} \mathrm{cm}^{-3}\right)$ than in the dry season $\left(2.04 \pm 0.22 \mathrm{mg} \mathrm{cm}^{-3}\right)$ for both 10-25-YO planted and $>50$-YO natural (Fig. 6A). 


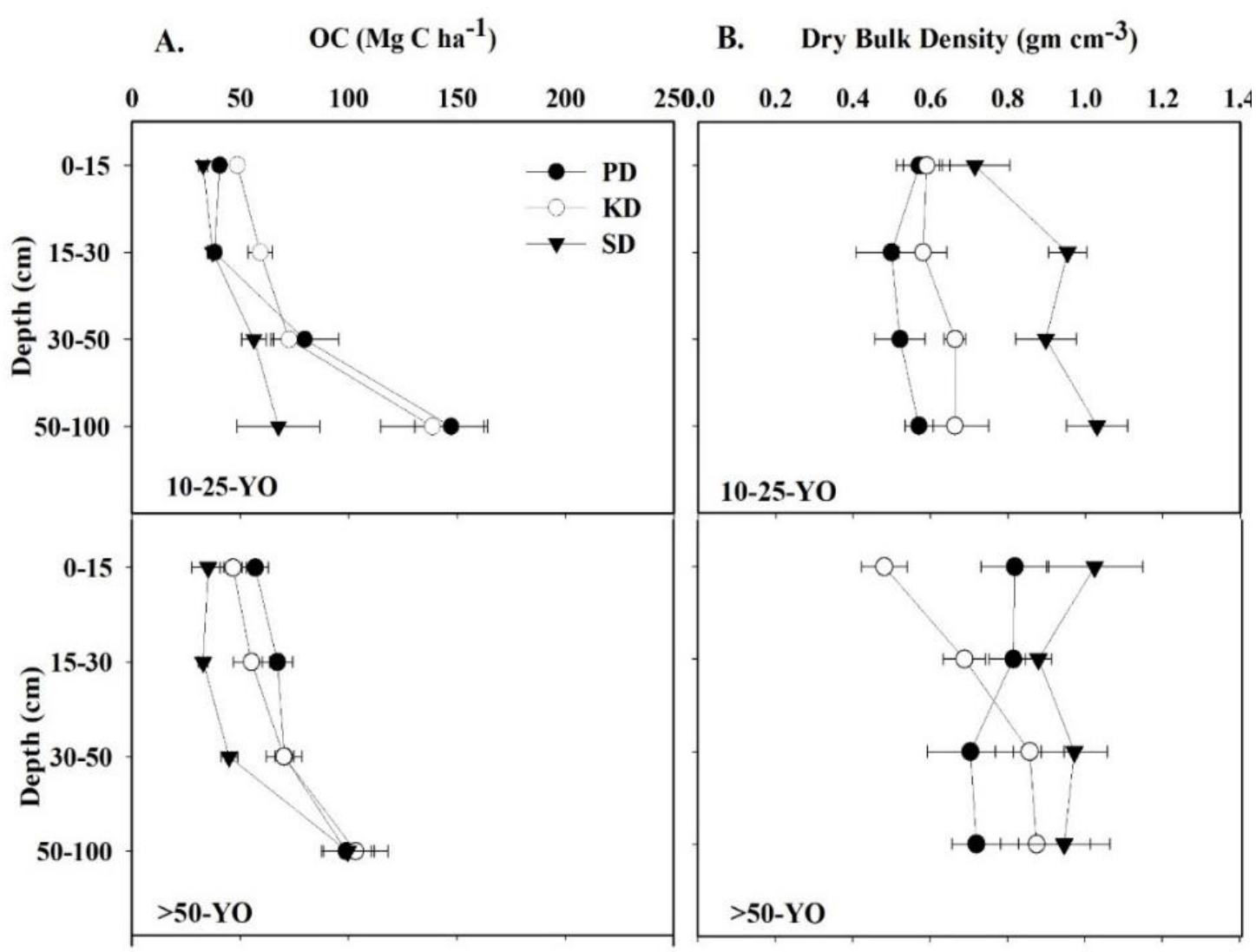

Figure 6. Mean OC-S (Mg C ha-1; A) and Dry Bulk Density $\left(\mathrm{g} \mathrm{cm}^{-3}\right.$; B) at different depths of 1025-YO planted and >50-YO natural mangrove forests in Trang, Thailand. Error bars are for S.E.

Table 3. The result of Two-Way ANOVA determining the effects on $C$ of the following factors: Three different sites with 10-25-YO planted and >50-YO natural mangroves at four different depths $(n=15)$

\begin{tabular}{c|ccc|ccc|cccc}
\hline \multirow{2}{*}{$\begin{array}{c}\text { Sources of } \\
\text { Variation }\end{array}$} & \multicolumn{9}{|c|}{ Sites } \\
\cline { 2 - 11 } & SD & df & SS & $\boldsymbol{p}$ & df & SS & $\boldsymbol{p}$ & df & SS & $\boldsymbol{p}$ \\
\hline Age & 1 & 0.18 & 0.450 & 1 & 0.05 & 0.020 & 1 & 0.00 & 0.680 \\
Depth & 3 & 0.56 & $<0.001$ & 3 & 0.60 & $<0.001$ & 3 & 0.69 & $<0.001$ \\
Age vs. Depth & 3 & 0.18 & 0.090 & 3 & 0.09 & 0.390 & 3 & 0.36 & $<0.001$ \\
\hline
\end{tabular}

\section{Organic Carbon derived from Organic Particulate Matter (OC-POM)}

The organic carbon derived from decayed materials in the mangroves was classified as humus/particulate organic matter (POM) in this study. The OC-POM compared between ages was higher in $>50$-YO natural forest $\left(74.29 \pm 33.57 \mathrm{Mg} \mathrm{C} \mathrm{ha}^{-1}\right)$ than in the 10-25-YO planted forest (52.27 $\pm 9.45 \mathrm{Mg} \mathrm{C} \mathrm{ha}^{-1}$; $\mathrm{t}(25)=2.44 ; p<0.05$; Table 1; Fig. 7A). The peak of OC-POM was in May for both 10-25-YO planted forest (37.42 $\left.\pm 5.43 \mathrm{Mg} \mathrm{C} \mathrm{ha}^{-1}\right)$ and for >5O-YO natural forests $\left(35.01 \pm 10.76 \mathrm{Mg} \mathrm{C} \mathrm{ha}^{-1}\right)$. 

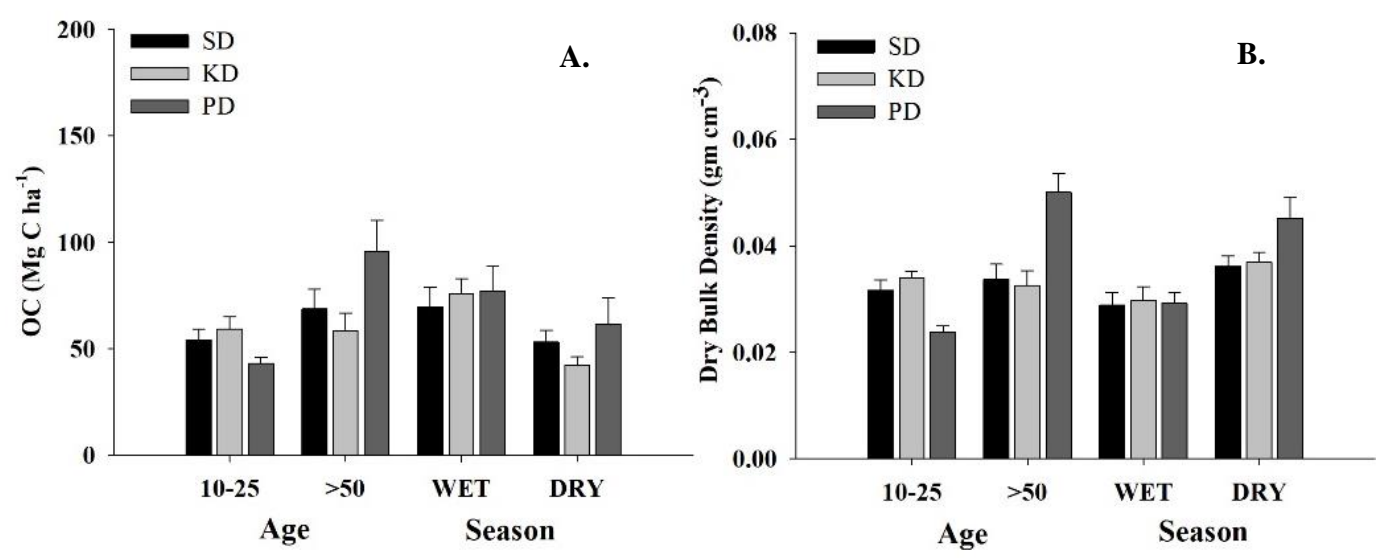

Figure 7. OC-POM in $\mathrm{MgCh} \mathrm{C}^{-1}$ (A) and Dry bulk density in $\mathrm{g} \mathrm{cm}^{-3}$ (B) from OM/humus in Trang districts. Error bars are for S.E.

During wet and dry seasons the OC-POM followed the same trend as OC-S, being higher in the wet season $(74.15 \pm 5.48 \mathrm{Mg} \mathrm{C} \mathrm{ha-1)} \mathrm{than} \mathrm{in} \mathrm{the} \mathrm{dry} \mathrm{season}$ (52.41 $\pm 5.69 \mathrm{Mg} \mathrm{C}^{-1} ; p<0.05$; Table 3; Fig. 7B).

Mean quarterly data of OC-POM varied significantly in $>50$-YO natural forests (Factorial ANOVA, $\mathrm{F}(3,732.88)=3.21 ; p<0.05)$; and in the three different sites (Factorial ANOVA, F $(14,1,750)=3.21 ; p<0.05)$. The 10-25-YO followed the same pattern, (Factorial ANOVA, $\mathrm{F}(3,1,824)=3.21 ; p<0.05$ and $\mathrm{F}(14,86.44)=1.68$; $p<0.05)$. OC-POM in the three sites were highest in August in PD 10-25-YO planted forest $\left(59.23 \pm 27.72 \mathrm{Mg} \mathrm{C} \mathrm{ha}{ }^{-1}\right)$ and lowest also in PD 10-25-YO planted forest (8.07 $\pm 0.85 \mathrm{Mg} \mathrm{C} \mathrm{ha}^{-1}$; Fig. 7A). The DBD followed the same pattern, with PD >50-YO natural forest being the highest at $1.97 \pm 0.22 \mathrm{~g} \mathrm{~cm}^{-3}$ (Fig. $7 B$ ).

In contrast to OC-S, the OC-POM showed variations in the $0-30 \mathrm{~cm}$ soil depth. Tested with linear regression, the mean quarterly POM (\%) and OC-POM (Mg C ha-1) appear to have no significant relationship $(p>0.05)$ and only have a weak correlation $\left(\mathrm{R}^{2}=0.25\right)$ (Fig. 8A). DBD and OC-POM were not correlated either $(p<0.05$ and $\left.\mathrm{R}^{2}=0.26\right)($ Fig. 8B).
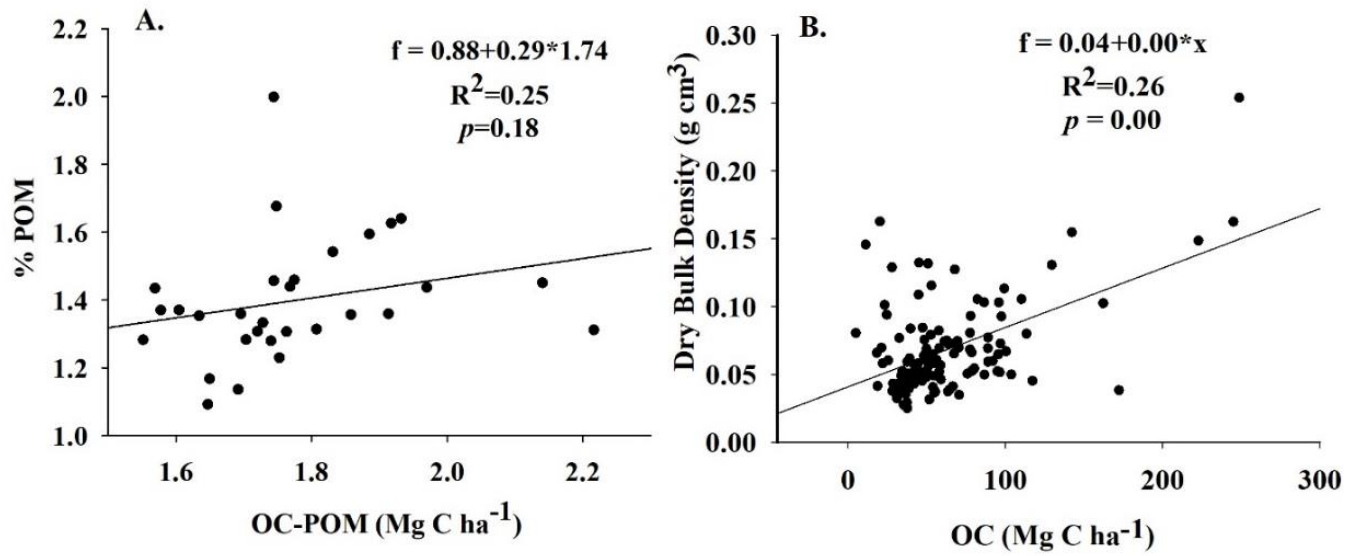

Figure 8. The log-transformed percent $O M$ and $O C$ (A), and DBD and $O C$ (B). All values are derived from $O M$ 


\section{Soil Characteristics}

This study observed that silt/clay was the dominant soil type in both 10-25-YO and $>50-$ YO mangrove forests in Trang (Fig. 9A-B). At depths of 0-15 and 15-30 cm, silt/clay dominated in the three sites and was followed by very fine sand and fine sand.

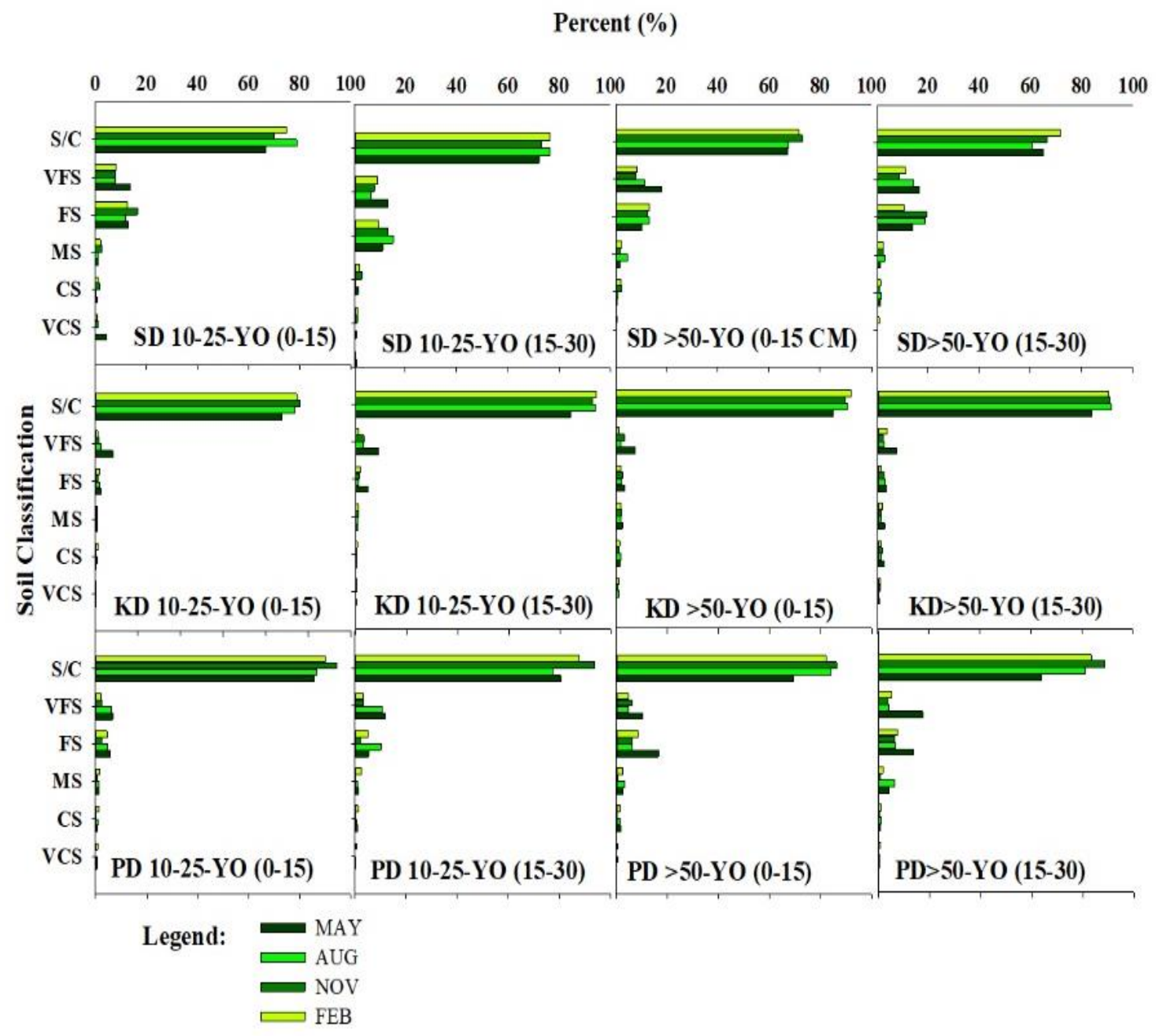

Figure 9. Dominant characteristics (\%) of soil in Trang, Thailand. VCS-very coarse sand, CScoarse sand, MS-medium sand, FS-fine sand, VFS-very fine sand and S/C-silt/clay

\section{The Soil Properties}

Figure 10 shows the soil temperature for the $10-25-\mathrm{YO}$ planted and $>50-\mathrm{YO}$ natural mangrove forests. The mean soil temperature was $27.99 \pm 1.11^{\circ} \mathrm{C}$ in $>50$-YO forest and $28.08 \pm 0.55$ in $10-25$-YO forest. The mean value was higher in the wet season $\left(\mathrm{M}=28.08 \pm 0.14^{\circ} \mathrm{C}\right)$ than in the dry season $\left(\mathrm{M}=27.72 \pm 0.21^{\circ} \mathrm{C}\right)$; but this difference was not statistically significant $(p>0.05)$. The average daily rainfall during the sampling period was highest in August (14.90 $\pm 4.27 \mathrm{~mm})$, followed by May $(12.81 \pm 3.65 \mathrm{~mm})$ and November 2017 (12.81 $\pm 3.65 \mathrm{~mm} /$ day) (Figs. 10 and 11). February 2018 had the lowest rainfall $(8.03 \pm 2.55 \mathrm{~mm})$. 


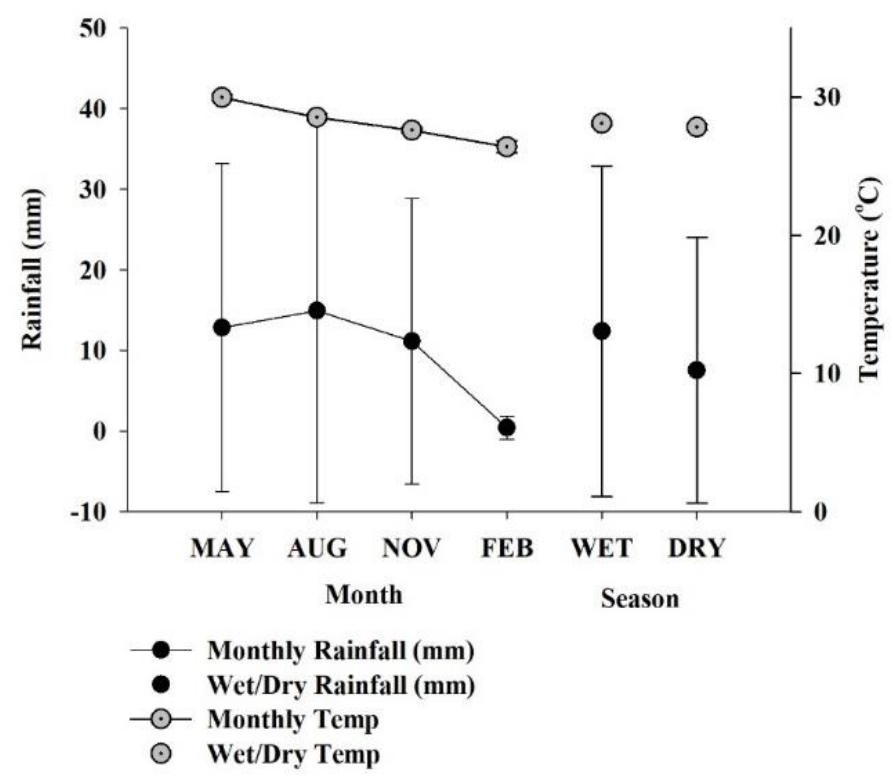

Figure 10. Mean daily rainfall data $(\mathrm{mm})$ and temperature $\left({ }^{\circ} \mathrm{C}\right)$ during the sampling periods (Source: Meteorological Department, Thailand)

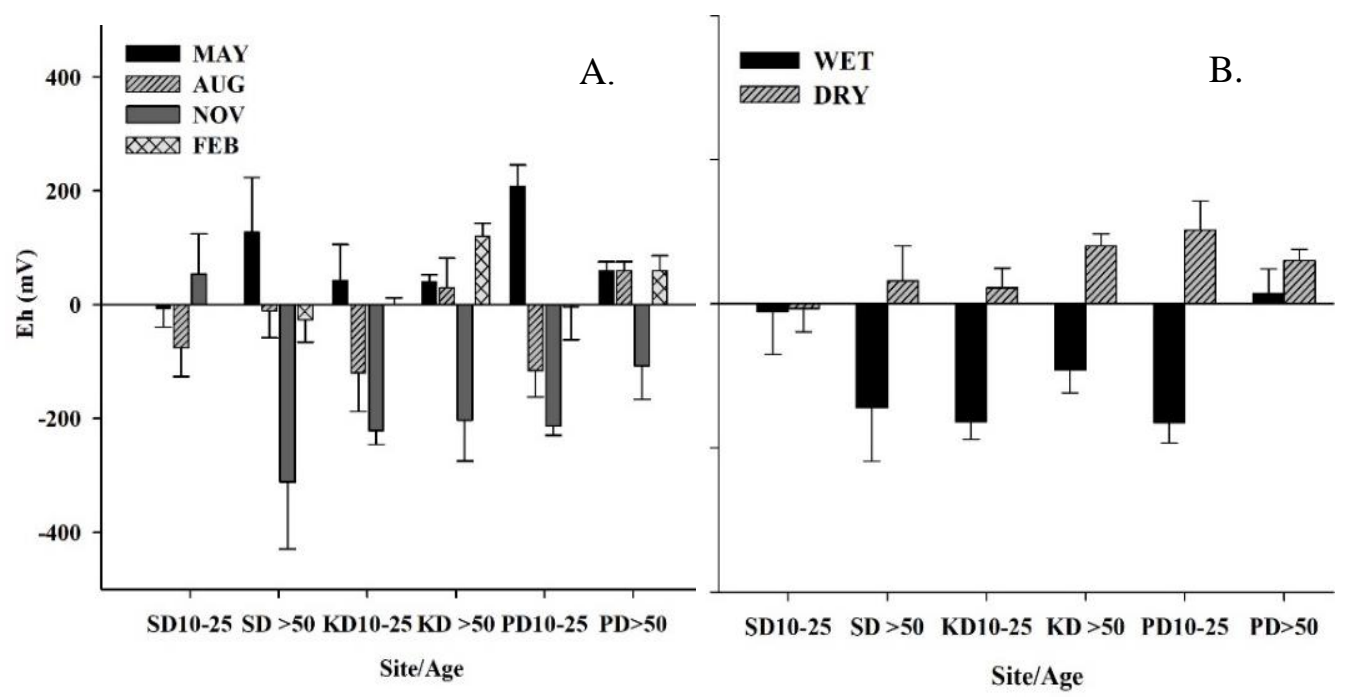

Figure 11. Eh ( $\mathrm{mV}$ ) quarterly (A) and during the wet and dry seasons (B), in Trang, Thailand

The $\mathrm{pH}$ of the soil had lower values in KD for both $10-25$-YO planted $(6.45 \pm 0.07)$ and $>50$-YO natural forest $(6.45 \pm 0.04)$, while the highest $\mathrm{pH}(6.91 \pm 0.09)$ was observed in PD for the $>50-Y O$ natural forest (Fig. 3). The results were higher in the wet season $(6.77 \pm 0.08)$ than in the dry season $(6.59 \pm 0.04 ; p<0.05)$. Eh potential of the soil is characteristically anoxic ranging in $-9.40 \pm 36.36 \mathrm{mV}$ in SD 10-25-YO planted and in $-62.40 \pm 19.00 \mathrm{mV}$ in $\mathrm{KD} 10-25-\mathrm{YO}$ planted forests (Fig. 11). The comparison between two seasons showed $-93.62 \pm 21.59 \mathrm{mV}$ during the wet season with the most anoxic soil found in PD 10-25-YO planted forest $(-163.72 \pm 24.34 \mathrm{mV})$. Variation of Eh between the two seasons was statistically significant ( $p<0.05$; Fig. 11). 


\section{Discussion}

\section{Above and Below Ground Carbon, Dry Bulk Density and Organic Carbon from Particulate Organic Matter}

This study investigated and monitored the organic carbon content in the 10-25-YO planted and $>50-Y O$ natural mangrove forests in the Southern part of Thailand. The findings showed that the variation of CAGB differed due to dense growth of $R$. apiculata in the 10-25-YO planted forest; while the $>50-\mathrm{YO}$ natural forests had mixed old stands of Avicennia spp., Rhizophora, Bruguiera spp, Ceriops, and Xylocarpus spp. (Fig. 2). The composition of 11 species in $>50$-YO natural forest gave taller plants and a wider range of sizes (i.e. diameter at breast height of trees) and densities (Fig. 2) compared to the 10-25-YO planted with only 3 species, and dominated by $R$. apiculata. In particular, the dense and mono-stand vegetation in KD 10-25-YO planted in unutilized shrimp pond area (Cadiz and Chotikarn, 2018) confirmed these species as the main contributors to CAGB (Figs. 1 and 2).

The estimates of CAGB at three sites show trends comparable to the estimates obtained by Komiyama et al. (2008), and Ong et al. (1995). Ranges of CAGB values around Asia were studied (Table 3), and Malaysia showed $116.79 \mathrm{t} \mathrm{C}^{-1}$ (Chandra et al., 2011) and $305.46 \mathrm{t} \mathrm{C} \mathrm{ha}^{-1}$ for natural and $122.78 \mathrm{t} \mathrm{C} \mathrm{ha}^{-1}$ in degraded areas (Zhila et al., 2014). Putz and Chan (1986) reported $409 \mathrm{t} \mathrm{C} \mathrm{ha}^{-1}$ in 30-YO and Ong et al. (1995) reported $114 \mathrm{t} \mathrm{C} \mathrm{ha}^{-1}$ in a 20-year old dominantly $R$. apiculata in Matang Mangrove Reserve. The Philippines were in the range from 291.0 to $1578.6 \mathrm{t} \mathrm{C} \mathrm{ha}^{-1}$ (Abino et al., 2014) in natural areas and $282.64 \mathrm{t} \mathrm{ha}^{-1}$ in 27-YO planted areas (Castillio and Breva, 2012). The 10-years old Rhizophora mucronata Lamk. and Bruguira cylindrica (L.) Blume planted in excavated shrimp pond areas in Khanom, Nakorn Sri Thammarat, Thailand, had $98.7 \mathrm{t} \mathrm{C} \mathrm{ha}^{-1}$ and $28.8 \mathrm{t} \mathrm{C} \mathrm{ha}^{-1}$ (Matsuie et al., 2012). It was also established in Ao Sawi, Thailand, that the above-ground biomass in old forest stands tends to have a higher capacity of carbon (about 27\%) (Alongi et al., 2001); while this study had a similar trend of higher $\mathrm{CAGB}$ in $>50-\mathrm{YO}$ natural forest $\left(243.88 \pm 22.24 \mathrm{t} \mathrm{C} \mathrm{ha}^{-1}\right)$ than in the $10-25$-YO planted forest $\left(143.37 \pm 19.13 \mathrm{t} \mathrm{C} \mathrm{ha}^{-1}\right.$; $p<0.05)$. This is caused by more species in the natural stands than in planted stands, highlighting that the species diversity affects the production of CAGB (MacKenzie et. al., 2016).

Soil in mangroves is known as the largest source of organic carbon pool (Alongi et al., 2016), and carbon stored in the soil is the best indicator of productivity in the mangrove ecosystem (Boullion et al., 2008). The distribution and content of carbon stored in the soil are most likely dependent in geographic characteristics of the entire mangrove ecosystem, since all the established plots of the studied sites were directly connected with runoffs from tributaries of rivers, creeks/canals and adjacent shrimp ponds (Fig. 1) for ease and accessibility of sampling. However, we found that the similarities of OC-S content in both KD and PD have topographic influence as well. Unlike SD with lower OC-S because of the elevated topography characterized by the high boulders of crab mounds in both 10-25-YO planted and $>50$-YO natural mangrove forests (Fig. 1A-B). We observed that the large boulder crab mounds affect the consistency in coring the soil sediments. The crab mounds once covered the forest floor of the mangroves, and there is a high tendency to core the crab mounted areas instead of coring the forest floor; thus affecting the production of OC-S. These inconsistencies in sampling mangrove carbon affect the OC-S values obtained. 
Between planted and natural stands of mangroves, this study observed that OC-S stored in the10-25-YO planted $\left(272.49 \pm 19.16 \mathrm{Mg} \mathrm{C}^{-1}\right)$ is higher than in the $>50$-YO natural forest $\left(254.73 \pm 11.74 \mathrm{Mg} \mathrm{C} \mathrm{ha}^{-1}\right)$. Categorically higher values of OC-S in the 10-25-YO planted forests were due to the higher density of trees (Table 1). This characteristic was observed in the 10-25-YO planted forest in KD with the highest OC-S of $317.75 \pm 16.18 \mathrm{Mg} \mathrm{C} \mathrm{ha}^{-1}$. The compacted soil in the pond perhaps has a tendency and high ability to hold and store sediments and organic matter for a certain period of time, facilitating growth of these 10-25-YO planted forests (Fig. 1A,B and D). Another contributing factor in OC-S production is the possibility of higher turn-over rate of defoliation from younger trees apart from dense cover (as closely planted in the shrimp pond areas).

However, the overall mean OC-S obtained in this study was below the global value of $749 \mathrm{Mg} \mathrm{C}$ ha $^{-1}$ ) (Kauffman et al., 2018) but still comparable to observations in Singapore, Vietnam, Philippines, India, Africa, Palau and Micronesia and Brazil.

The temporal (dry and wet season) variations contributed to the variation of OC-S in the mangrove ecosystem. The higher OC-S during the wet season indicates that carbon buried in the soil favored by the right amount of rainfall and temperature (Fig. 10). Such that rainfall allows more water flow the movement (i.e., like density stratification and vertical circulation) (Mazda et al., 2007) which enhance the biotic activity of the mangrove soil and potentially contributing the OC-S production.

The overall trends in OC-S was to have more OC-S in deeper soil (50-100 cm depth) and this was particularly observed in the 10-25-YO planted forests in KD and PD (Figs. 5 and 6 ) where the OC-S increased with depth. Similar trend has been observed in the northeastern Brazilian mangroves (Kauffman et al., 2017) and Central-Western Region of Venezuela (Barreto et al., 2016). However, some studies have revealed the opposite trend with the concentration of carbon tending to decrease with depth (CeronBreton et al., 2014), because carbon also tends to be influenced by the rate of production of organic matter and not only the rate of decay (Alongi et al., 2016).

The derived OC-POM taken only at $0-30 \mathrm{~cm}$ depth is of primary concern in this study since rich POM is mostly found on surface of the forest floor. The result suggests no direct relationship between percent organic matter and OC-POM production (Fig. 8A). This indicates that OC-POM settled deeper while the OM settled more at the surface layer $(0-30 \mathrm{~cm}$ depth) of the soil. The settled OM on soil surface allows more time to reach deeper prior to the integration of the OC-POM. The ingtegration of organic matter in the forest floor and soil profile will only come after the integration and mineralization process (Salmo et al., 2013). While this increases the production of OM in the surface layer, there is also a presence of new litter (Punwong et al., 2018) and then this gradually decreases in the deeper part of the soil. This study indicates that the source of organic matter was mainly the shrimp ponds channeled through canals and rivers (Figs. 1 and 2). Hence, the topography at a site influenced the flows and transport of $\mathrm{OM}$ in the mangrove stands. Apart from the allochthonous material deposits in the mangrove ecosystem, the presence of different species, tidal range, topography, sediment chemistry, community structure, and substrate characterisitcs (Dittmar and Lara, 2001; Chaikaew and Chavanich, 2017) therefore affect the derived OC-POM.

Overall, the variation and range of OC in mangroves is affected by how sampling is done, along with plot size, precision, and accuracy of allometric models (Rodriguez et al., 2014), species diversity (MacKenzie et al., 2016), hydrogeomorphology, climate 
and seasons (Ceron-Breton et al., 2014), while this study also considered soil depth induced variations in carbon measurements.

\section{Soil Properties}

The significance of soil characteristics such as soil type and composition are most influential in a mangrove ecosystem. The different mangrove species have different affinities to soil types (Calumpong and Cadiz, 1997) that influence the growth and survival of planted mangroves (Salmo et al., 2013). In this study, the results indicate that the soil type in most of the studied areas was muddy with typical silt/clay characteristics exhibited in the mangroves. As described regarding the study site, the deposition of fine particles that are carried with overflow from the big canals and rivers influenced stored carbon in mangroves. Since all the plots assessed were close to rivers, creeks or canals for ease and accessibility of working (Figs. 1 and 2), they had fine sand deposits and dense mangrove growth (Punwong et al., 2018), with silt/clay soil. Although the coring of the sediment for soil profile in this study was limited to $0-30 \mathrm{~cm}$ depth, the results suggest that silty/clay characteristics in both 10-25-YO planted and $>50$-YO natural forests tend to hold more carbon as one samples deeper (Fig. 6A). This characteristic contributes to the potential to retain organic carbon in the soil to influence DBD (Barreto et al., 2016; Phang et al., 2017). The soil profile in mangroves is generally dominated by silt/clay (Fig. 9) which is rich in organic clay and humus due to the biotic activity in the soil (Mazda et al., 2007). This is good for storing OC. This characteristic of soil is also found in Ao Nam Bor, Phuket, Thailand (Kristensen et al., 1995), following also the physical attributes in all the mangrove soils worldwide (Hossain and Nuruddin, 2016). However, the fact that mangroves exist in a wide range of soil types, even potentially within a single study area, contributes to large variability in reported soil C stocks.

Mangroves thrive well in tropical climate. The higher OC-S during wet season was enhanced by rainfall. In the process, the hydrological characteristics attributed by rainfall enhanced the biotic activity of the soil, thus influenced carbon stored in the mangrove soil. On May 2017 during the onset of rainy season, the second highest rainfall took place (Fig. 8), while February 2018 was the peak of the dry season, and rain occurred during sampling. However, the soil temperature averages over wet and dry seasons were considerably high, ranging within $24.76-30.02^{\circ} \mathrm{C}$ compared to $26.99-27.69^{\circ} \mathrm{C}$ in Phetchaburi (Jitthaisong et al., 2012) or 25.8 to $28.9^{\circ} \mathrm{C}$ in Tungka Bay, Chumpon, Thailand (Matsuie et al., 2015). Temperature and precipitation are known to influence the survival and growth of mangroves (Numbere and Camilo, 2017), as well as carbon densities.

Evidence of low $\mathrm{pH}$ and high redox was observed in KD during the wet season. The 10-25-YO planted area in KD located nearby a rubber plantation, and a former site with land-use change from shrimp farming activities. Perhaps this activity had left nutrients to influence Eh. Categorically, all sites for both stands had highly anoxic soil during the wet season (Fig. 11A). Anoxic soil causes faster decomposition of organic matter as revealed by the higher OC-POM during the wet season (Fig. 7A). What made Eh high in $\mathrm{KD}$ was that the planted mangroves were in an intact abandoned shrimp pond. The infiltration of rainfall in the pond took longer time, while allowing organic matter to settle in the pond. Further, the OC is highly correlated with $\mathrm{pH}$ and Eh because of its relation to transport in the mangrove ecosystem. Also the mobilities of phosphorus and magnesium depend on $\mathrm{pH}$ and Eh (Matsui et al., 2015). In addition, disturbing 
mangrove areas triggered the formation of pyrite (a feature of mangrove sediments), which also influenced $\mathrm{pH}$ and Eh. This oxidation process occurs typically after a mangrove forest is cleared for aquaculture purposes, like shrimp ponds (Kristensen et al., 1995). Overall, however, neutral soil characteristics were observed in this study.

\section{Conclusions}

1) Based on this study, the knowledge gaps on the carbon storage potential of restored mangrove (mostly planted in abandoned shrimp ponds) and mangrove on natural stands were addressed. Sources and sinks of carbon in both types of stands were found in CAGB, OC-S and PO-POM, and their differences were influenced by the community structure and vegetation. The observed large variations in CAGB were likely due to the complexity of species; such as in $>50$-YO natural forests had 11 species while the 10-25-YO planted mangrove only had 3 species and was dominated by $R$. apiculata, in contrast to higher densities in planted stands than natural stands. Therefore, this study suggests that conservation of mangroves in natural stands remains the first and foremost source and sink of C.

2) While the soil samples cored in crab mounted areas such as in SD showed lower OC-S densities it is best to recommend that further study should be conducted at other sites with the same crab mounted characteristics. This is to ensure that a well-defined inventory approach in assessing ecosystem $\mathrm{C}$ stocks is necessary to better account for the heterogeneity in topographic characteristics.

3) This study also demonstrated that both stands of mangroves act as carbon sinks, and therefore planted stands are also carbon sinks similar to the natural stands, provided similar geomorphic and topographic characteristics. The significance of restored mangroves is that even relatively young stands of mangrove forest can sequester a substantial amount of carbon, stored either aboveground in biomass or below ground in the soil. These findings provide additional information for developing strategies for the management of carbon in relation to land-use change (Donato et al., 2012), particularly on reverted shrimp pond areas.

4) Furthermore, all restoration activities need to be well maintained and sustained by the local people, who should appreciate the indirect values of mangroves, specifically as carbon sinks. Since only little is known and no particular research has been done on the active involvement (i.e., experiences and motivations) of the local community towards blue carbon governance (Thomas et al., 2014), and for better management, trainings of the local people for blue carbon initiatives and governance should also be initiated.

5) Overall, this study showed the potential of natural as well as planted stands of mangrove in storing carbon in order to encourage and pursue local sectors of Trang, Thailand and policy makers in both local and national agencies to continue the efforts in mangrove restoration, particularly in areas abandoned from aquaculture activities.

Acknowledgments. This research was funded by the Graduate School, Prince of Songkla University (PSU) under the Thailand Education Hub for ASEAN Countries (TEH-AC) and in part from PADI Foundation. We gratefully acknowledge The Department of Marine and Coastal Resources, Trang for the logistics support and Pathompong Pramneechote for his unselfish time all throughout the sampling; Mr. Jim Enright of Map Action Project (MAP, Asia), Trang for valuable assistance in choosing the study sites 
and Pimchanok Buapet, Paramita Punwong and Bradly Walters for their invaluable comments and suggestions. Authors would like to thank to Seppo Karrila and Research and Development Office, PSU for English proof.

Conflict of Interests. The authors confirm that there is no conflict of interests in publishing this paper.

\section{REFERENCES}

[1] Abino, A. C., Castillo, J. A., Lee, Y. J. (2014): Species Diversity, Biomass, And Carbon Stock Assessments Of A Natural Mangrove Forest In Palawan, Philippines. - Pak. J. Bot. 46(6): 1955-1962.

[2] Aksornkoae, S. (1993): Ecology and Management of Mangroves. - IUCN, Bangkok, Thailand. Dyna Print Ltd., 392/9 $2^{\text {nd }}$ Siam Square, Soi 5, Bangkok, Thailand 2-35.

[3] Aksornkoae, S. (2012): Mangroves... Coastal Treasure of Thailand. - The Journal of the Royal Institute of Thailand 1V: 73-75.

[4] Alongi, D. M., Wattayakorn, G., Pfitzner, J., Tirende, F., Zagorskis, I., Brunskill, G. J., Davidson, A., Clough, B. G. (2001): Organic carbon accumulation and metabolic pathways in sediments of mangrove forests in southern Thailand. - Marine Geology 179(1-2): 85-103.

[5] Alongi, D. M., Sasekumar, A., Chong, V. C., Pfitzner, J., Trott, L. A., Tirendi, F. (2004): Sediment accumulation and organic material flux in a managed mangrove ecosystem: estimates of land-ocean-atmosphere exchange in peninsular Malaysia. - Marine Geology 208: 383-402.

[6] Alongi, D. M., Murdiyarso, D., Fourqurean, J. W., Kauffman, J. B., Hutahaean, A., Crooks, S., Lovelock, C. E., Howard, J., Herr, D., Fortes, M., Pidgeon, E., Wagey, T. (2016): Indonesia's blue carbon: a globally significant and vulnerable sink for seagrass and mangrove carbon. - Wetlands Ecology 24: 3-13. https://doi.org/10.1007/s11273-0159446-y.

[7] Bantoon, S. (1994): Using simulation modeling and remote sensing technique for an impact study of shrimp farms on mangrove area and aquatic animal production at Welu estuary, Klung district, Chantaburi Province. - Unpublished MSc thesis, Chulalongkorn University.

[8] Barbier, E. B. (2008): In the wake of tsunami: Lessons learned from the household decision to replant mangroves in Thailand. - Resource and energy Economics 30(2): 229249. doi:10.1016/j.reseneeco.2007.08.002.

[9] Barreto, M. B., Moaco, S. L., Diaz, R., Barreto-Pittol, E., Lopez, L., do Carmo Ruaro Peralba, M. (2016): Soil organic carbon of mangrove forests (Rhizophora and Avicennia) of the Venezuelan Caribbean coast. - Organic Geochemistry 100: 51-61.

[10] Beaumont, N. J., Jones, L. M., Garbutt, A., Hansom, J. D., Toberman, M. (2014): The value of carbon sequestration and storage in coastal habitats. - Estuarine, Coastal and Shelf Science 137: 32-40. http://dx.doi.org/10.1016/j.ecss.2013.11.022.

[11] Boromthanarat, S., Cobb, S., Lee, V. (1991): Coastal Management in Pak Phanang: A Historical Perspective of Resources and Issues. - Hat Yai, Thailand: Coastal Resources Institute, Prince of Songkla University.

[12] Bouillon, S., Borges, A. V., Castañeda-Moya, E., Diele, K., Dittmar, T., Duke, N. C., Kristensen, E., Lee, S. Y., Marchand, C., Middelburg, J. J., Rivera-Monroy, V. H., Smith III, T. J., Twilley, R. R. (2008): Mangrove production and carbon sinks: A revision of global budget estimates. - Global Biogeochemical Cycles 22(2): 1-12.

[13] Braley, R. D. (ed.) (1992): The Giant Clam: Hatchery and Nursery Culture Manual. ACIAR Monograph 15: 144.

[14] Cadiz, P., Chotikarn, P. (2018): Biomass Estimates and Species Diversity of Natural and Planted Mangroves in Trang, Thailand. - Proceedings of the $1^{\text {st }}$ International Conference 
on Climate Change, Biodiversity, Food Security and Local Knowledge, 3-4 September 2018. Artha Wachana Christian University, Kupang, East Nusa Tenggara, Indonesia.

[15] Calumpong, H. P., Cadiz, P. L. (1997): Mangrove Rehabilitation Efforts in Bais Bay. Silliman Journal 37(3-4): 187-203.

[16] Calumpong, H. P., Meñez, E. (1997): Field Guide to the Common Mangroves, Seagrasses and Algae of the Philippines. - Bookmark, Inc. Makati City, Philippines.

[17] Calumpong, H. P., Cadiz, P. L. (2012): Mangrove Rehabilitation in Ticao Island, Masbate, Philippines. - SEARCA Agriculture and Development Discussion Paper Series: 2012-4(12).

[18] Castillo, J. A., Breva, L. (2012): Carbon Stock of four Mangrove Reforestation/Plantation Stands in the Philipines. - In: Palis, H., Pasicolan, S., Villamor, C. (eds.) Proceedings of the $1^{\text {st }}$ ASEAN Congress on Mangrove Research and Development (Century Park Hotel Manila, Philipines, December 3-7, 2012.

[19] Cerón-Bretón, J. G., Cerón-Bretón, R. M., Guerra-Santos, J. J., Córdova-Quiroz, A. C. (2014): Estimation of Regional Carbon Storage Potential in Mangrove Soils on Carmen Island, Campeche, Mexico. - In: Morgado, C. R. V., Esteves, V. (eds.) CO2 Sequestration and Valorization. IntechOpen, DOI: 10.5772/57055. Available from: https://www.intechopen.com/books/co2-sequestration-and-valorization/estimation-ofregional-carbon-storage-potential-in-mangrove-soils-on-carmen-island-campeche-mexico

[20] Chaikaew, P., Chavanich, S. (2017): Spatial Variability and Relationship of Mangrove Soil Organic Matter to Organic Carbon. - Applied and Environmental Soil Science 2017: 4010381. https://doi.org/10.1155/2017/4010381.

[21] Chandra, I. A., Seca, G., Abu Hena, M. K. (2011): Aboveground Biomass Production of Rhizophora apiculata Blume in Sarawak Mangrove Forest. - American Journal of Agricultural and Biological Sciences 6(4): 469-474.

[22] Department of Marine and Coastal Resource Research and Development (2015): DMCR Annual Report. - In: Handbook of Thailand Marine Coastal Resources. Ministry of Natural Resources and Environment. Printed by the Agricultural Cooperative Federation of Thailand., LTD. Bangkok. 249.

[23] Dittmar, T., Lara, R. J. (2001): Driving Forces Behind Nutrient and Organic Matter Dynamics in a Mangrove Tidal Creek in North Brazil. - Estuarine Coastal and Shelf Science 52(2): 249-259.

[24] Donato, D. C., Kauffman, J. B., MacKenzie, R. A., Ainsworth, A., Pfleeger, A. Z. (2012): Whole-island carbon stocks in the tropical Pacific: Implications for mangrove conservation and upland restoration. - Journal of Environmental Management 97: 89-96.

[25] FAO (2007): The World's Mangroves 1980-2005. - Electronic Publishing and Support Branch. Communication Division. FAO. Rome, Italy.

[26] Fast, A. W., Menasvita, P. (2003): Mangrove Forest recovery in Thailand. - World Aquaculture 7: 6-9.

[27] Giri, C., Ochieng, E., Tieszen, L. L., Zhu, Z., Singh, A., Loveland, T., Masek, J., Duke, N. (2011): Status and distribution of forests of the world using earth observation satellite data. - Global Ecology and Biogeography 20(1): 154-159.

[28] Havanond, S. (1997): Mangrove Forest Conservation in Thailand. - Biology Bulletin 32(2): 97-102.

[29] Horstman, E., Dohmen-Janssen, M., Narra, P., van den Berg, N.-J., Siemerink, M., Balke, T., Bouma, T., Hulscher, S. J. M. H. (2012): Wave Attenuation in Mangrove forests: field Data Obtained in Trang. - Coastal Engineering 2012.

[30] Horstman, E., Dohmen-Janssen, C. M., Hulscher, S. J. M. H. (2013): Flow routing in mangrove forests: A field study in Trang province, Thailand. - Continental Shelf Research 71: 52-67.

[31] Hossain, M. D., Nuruddin, A. A. (2016): Soil and Mangrove: A Review. - Journal of Environmental Science and Technology 9(2):198-207. 
[32] Howard, J., Hoyt, S., Isensee, K., Pidgeon, E., Telszewski, M. (eds.) (2014): Coastal Blue Carbon: Methods for assessing carbon stocks and emissions factors in mangroves, tidal salt marshes, and seagrass meadows. - Conservation International, Intergovernmental Oceanographic Commission of UNESCO, International Union for Conservation of Nature. Arlington, Virginia, USA.

[33] Hoyle, F. (2013): Managing Soil Organic Matter: A practical guide. - Grains Research and Development Corporation (GRDC).

[34] Hutchings, P., Saenger, P. (1987): The Ecology of Mangroves. - University of Queensland Press. Box 42, Sta. Lucia Queensland, Australia.

[35] Jitthaisong, O., Dhanmanonda, P., Chunkao, K., Teejuntuk, S. (2012): Water Quality from Mangrove Forest: The King's Royally Initiated Laem Phak Bia Environmental Research and Development Project, Phetchaburi Province, Thailand. - Modern Applied Science 6(8).

[36] Kauffman, J. B., Donato, D. C. (2012): Protocols for the measurement, monitoring and reporting structure, biomass and carbon stocks in mangrove forests. - CIFOR, Bogor, Indonesia, Working Paper 86.

[37] Kauffman, J. B., Bhomia, R. K. (2017): Ecosystem carbon stocks of mangroves across broad environmental gradients in West-Central Africa: Global and regional comparisons. - PLOS ONE 12(11): e0187749. https://doi.org/10.1371/journal.pone.0187749.

[38] Kauffman, J. B., Bernardino, A. F., Ferreira, T. O., Bolton, N. W., Gomes, L. E., Nobrega, G. N. (2018): Shrimp ponds lead to massive loss of soil carbon and greenhouse gas emissions in northeastern Brazilian mangroves. - Ecology and Evolution 8(2): 55305540.

[39] Komiyama, A., Ong, J. E., Poungparn, S. (2008): Allometry, biomass, and productivity of mangrove forests: A review. - Aquatic Botany 89(2): 128-137.

[40] Kristensen, E., Holmer, M., Banta, G. T., Jensen, M. H., Hansen, K. (1995): Carbon, nitrogen and sulfur Cycling in Sediments of the Ao Nam bor Mangrove forest, Phuket, Thailand: A Review. - Phuket Mar. Biol. Cet. Res. Bull. 60: 37-64.

[41] Land Development Department. (2013): Land Use Map in Trang. - The Geoinformatics Research Center for Natural Resource and Environment. Prince of Songkhla University.

[42] Lewis, R. R. (2005): Ecological Engineering for successful management and restoration of mangrove forests. - Ecological Engineering 24(4): 403-418.

[43] MacKenzie, R. A., Foulk, P. B., Klump, J. V., Weckerly, K., Purbospito, J., Murdiyarso, D., Donato, D. C., Nam, V. N. (2016): Sedimentation and belowground carbon accumulation rates in mangrove forests that differ in diversity and land use: a tale of two mangroves. - Wetlands Ecology Management 24(2): 245-261.

[44] Matsui, N., Morimune, K., Meepol, W., Chukwamdee, J. (2012): Ten Year Evaluation of Carbon Stock in Mangrove Plantation Reforested from an Abandoned Shrimp Pond. Forests 3(2): 431-444. doi:10.3390/f3020431.

[45] Matsui, N., Meepol, W., Chukwamdee, J. (2015): Soil Organic Carbon in Mangrove Ecosystems with Different Vegetation and Sedimentological Conditions. - Journal of Marine Science and Engineering 3(4): 1404-1424.

[46] Mazda, Y., Wolanski, E., Ridd, P. V. (eds.) (2007): The Role of Physical Processes in Mangrove Environments: Manual for the preservation and utilization of mangrove ecosystems. - TERRAPUB. Sansei Jiyugaoka Haimu, 27-19 Okusawa 5-chrome, Setagaya-ku, Tokyo, Japan.

[47] Mcleod, E., Chmura, G. L., Bouillon, S., Salm, R. V., Björk, M., Duarte, C. M., Lovelock, C. E., Schlesinger, W. H., Silliman, B. R. (2011): A blueprint for blue carbon: toward an improved understanding of the role of vegetated coastal habitats in sequestering CO2. - Front Ecol Environ 9(10): 552-560.

[48] Numbere, A. O., Camilo, G. R. (2017): Effect of Temperature and Precipitation on Global Mangrove Rhizophora Species Distribution. - American journal of Environmental Sciences 13(5): 342-350. DOI: 10.3844/ajessp.2017. 
[49] Ong, J. E., Khoon, G. W., Clough, B. F. (1995): Structure and Productivity of a 20-year old stand of Rhizophora apiculata Bl. Mangrove forest. - Journal of Biogeography 22(23): 417-424.

[50] Phang, V. X. H., Chou, L. M., Friess, D. A. (2017): Ecosystem carbon stocks across a tropical intertidal habitat mosaic of mangrove forest, seagrass meadow, mudflat, and sandbar. - Earth Surface Processes and Landforms 40(10): 1387-1400. doi: 10.1002/esp.3745.61.

[51] Primavera, J. H., Esteban, J. M. A. (2008): A review of mangrove rehabilitation in the Philippines: successes, failures and future prospects. - Wetlands Ecology Management 16: 345-358.

[52] Punwong, P., Sritrairat, S., Selby, K., Marchant, R., Pumijumnong, N., Traiperm, P. (2018): An 800 year record of mangrove dynamics and human activites in the upper Gulf of Thailand. - Veget Hist Archeobot 27: 535-549. DOI 10.1007/s00334-017-0651-x.

[53] Putz, F. E., Chan, H. T. (1986): Tree Growth, Dynamics, and Productivity in a Mature Mangrove forest in Malaysia. - Forest Ecology and Management 17(2-3): 211-230.

[54] Rodrigues, D. P., Hamacher, C., Estrada, G. C. D., Soares, M. L. G. (2014): Variability of carbon content in mangrove species: Effect of species, compartments, and tidal frequency. - Aquatic Botany 120(Part B): 346-351.

[55] Romanach, S. S., DeAngeles, D. L., Koh, H. L., Li, Y., Teh, S. Y., Barizan, R. S. R., Zhai, L. (2018): Conservation and resoration of mangroves: Global status, perspectives, and prognosis. - Ocean and Coastal Management 154: 72-82.

[56] Saenger, P., Hegerl, E. J., Davie, J. D. S. (eds.) (1983): Global Status of Mangrove Ecosystem. - International Union for Conservation of Nature and Natural Resources.

[57] Salmo, S. G., Lovelock, C., Duke, N. C. (2013): Vegetation and soil characteristics as indicators of restoration trajectories in restored mangroves. - Hydrobiologia 720: 1-18.

[58] Schumacher, B. A. (2012): Methods for the Determination of Total Organic Carbon (TOC) in Soils and Sediments. - The United States Environmental Protection Agency, Environmental Sciences Division National Exposure Research Laboratory. Ecological Risk Assessment Support Center Office of Research and Development US. Environmental Protection Agency.

[59] Thampanya, U., Vermaat, J. E., Sinsakul, S., Panapitukkul, N. (2006): Coastal erosion and mangrove progradation of Southern Thailand. - Estuarine, Coastal and Shelf Science 68(1-2): 75-85.

[60] Thomas, S. (2014): Blue carbon: Knowledge gaps, critical issues, and novel approaches. - Ecological Economics 107: 22-28.

[61] Tomlinson, P. B. (1986): The Botany of Mangroves. - Cambridge University Press, UK.

[62] UNEP (2004): Mangroves in the South China Sea. - UNEP/GEF/SCS Technical Publication.

[63] Valiela, A., Bowen, J. L., York, J. K. (2001): Mangrove Forests: One of the World's Threatened Major Tropical Environments. - Bioscience 51(10): 807-815.

[64] Yee, S. (2010): REDD and BLUE Carbon: Carbon Payments for Mangrove Conservation. - MAS Marine Biodiversity and Conservation Capstone Project, UC San Diego 24-27.

[65] Zhila, H., Mahmood, H., Rozaina, M. Z. (2014): Biodiversity and biomass of a natural and degraded mangrove forest of Peninsular Malaysia. - Environ Earth Science 71: 46294635. DOI 10.1007/s12665-013-2853-6. 